\title{
Relation between the Distribution of Aquatic Hyphomycetes in Japanese Lakes and Lake Types
}

\author{
by Shizuo Suzuki* and Hiroyoshi NimurA**
}

Received May 14, 1960

Many excellent works on aquatic Hyphomycetes of fresh-water lakes have been published in Europe and America during the past two decades. Among the contributions the writers recall the names of Ingold $^{1-11}$ ), Ranzoni ${ }^{12,}{ }^{13}$ ), Nilsson ${ }^{14}$ ), Tubaki ${ }^{15}$ ) and others ${ }^{16,17}$ ). These investigators, however, studied mainly the distribution and taxonomy of the fungi, and paid little attention to the ecology of them. The writers have engaged in floristic and ecological studies of the aquatic fungi for several years, emphasizing the relation of the distribution of aquatic Hyphomycetes and the physicochemical properties of lake water.

\section{Experimental method}

The aquatic Hyphomycetes inhabits decaying leaves of trees fallen in lakes. Samples of these leaves were taken from lakes and those in stoppered bottles brought back into the laboratory. Six to ten leaves were collected from each lake. The collected materials were placed in petri dishes partially filled with autoclaved tap water. The specimens were allowed to stand at room temperature $\left(15-25^{\circ}\right)$ for 24 hours or more, then the conidia were found abundantly on the submerged leaves. The identification of species was carried out using a low power microscope. To make a detailed observation the fungus was stained with lactic phenol cotton blue.

\section{Distribution of aquatic Hyphomycetes}

The aquatic Hyphomycetes were widely distributed in the Japanese lakes. The distribution of the fungi, however, differed considerably with lake types (Table 1). On the basis of the qualitative data obtained, it is evident that the fungus flora was very rich in the harmonic lakes, while it was very poor in the dystrophic and acidotrophic lakes. In latter case, however, certain peculiar species adapting to the disharmonic water were found in large quantity.

Although eleven species were isolated from the harmonic lakes, Tetrachaetum elegans, Articulospora tetracladia, Lemonniera aquatica and Anguillospora longissima were the most prevalent in the lakes of this type. No aquatic Hyphomycetes, however, could be found in Lake Chüzenjiko and Towadako, which belong to the oligotrophic type.

On the other hand, aquatic Hyphomycetes were very slight or non-existent in the dystrophic lakes. As the lake water of this type contained large amounts of humic substances and reacted strongly acid, the physico-chemical specificities of the water may perhaps depress the activity of the fungi. Varicosporium elodeae seems to adapt to the dystrophic lakes. This species was found in neither the harmonic nor the acidotrophic lakes.

It is a very interesting fact that Tricladium gracile var. oxyphilum and Anguilio-

* Department of Microbial Chemistry, Faculty of Pharmacy, Tokyo College of Science.

** Botanical Institute, Faculty of Science, Tokyo University of Education. 
Table 1. The distribution of aquatic Hyphomycetes and lake types of Japanese lakes.

\begin{tabular}{|c|c|c|c|c|c|c|c|c|c|c|c|c|c|c|c|c|}
\hline 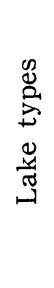 & Lakes & 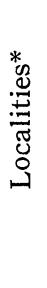 & 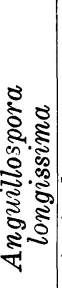 & 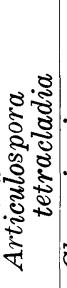 & 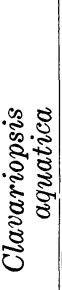 & 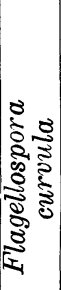 & 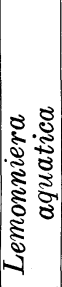 & 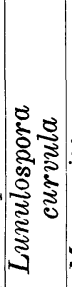 & 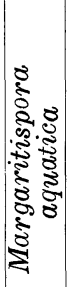 & 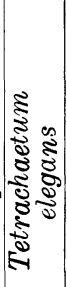 & 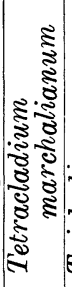 & 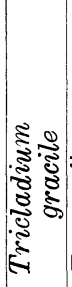 & 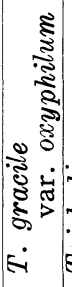 & 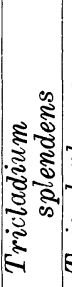 & 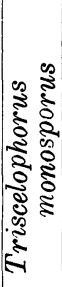 & 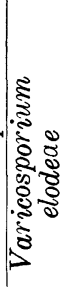 \\
\hline 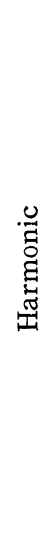 & $\begin{array}{l}\text { Tsukinuma } \\
\text { Kagaminuma } \\
\text { Shigenuma } \\
\text { Naganuma } \\
\text { Hyōtannuma } \\
\text { Yanaginuma } \\
\text { Nishiyanaginuma } \\
\text { Jimushonuma } \\
\text { Yarokunuma } \\
\text { Otomenuma } \\
\text { Kidoike } \\
\text { Tsutanuma } \\
\text { Biwaike } \\
\text { Maruike } \\
\text { Harunako } \\
\text { Soharako } \\
\text { Yamanakako } \\
\text { Chūzenjiko } \\
\text { Towadako }\end{array}$ & $\begin{array}{l}\text { A } \\
\text { A } \\
\text { A } \\
\text { A } \\
\text { A } \\
\text { C } \\
\text { C } \\
\text { C } \\
\text { C } \\
\text { C } \\
\text { F } \\
\text { A } \\
\text { F } \\
\text { F } \\
\text { D } \\
\text { C } \\
\text { G } \\
\text { E } \\
\text { A }\end{array}$ & $\begin{array}{l}0 \\
\dot{0} \\
\dot{0} \\
\dot{0} \\
\dot{0} \\
\dot{0} \\
\dot{0} \\
\dot{0} \\
\dot{.} \\
\dot{.} \\
\dot{.}\end{array}$ & $\begin{array}{l}\dot{0} \\
\dot{0} \\
\dot{0} \\
\dot{0} \\
\dot{0} \\
\dot{0} \\
\dot{0} \\
\dot{0} \\
\dot{0} \\
\dot{0}\end{array}$ & $\begin{array}{l}\bigcirc \\
\bigcirc \\
: \\
: \\
: \\
: \\
: \\
: \\
: \\
: \\
:\end{array}$ & $\begin{array}{l}\dot{:} \\
\dot{:} \\
\dot{:} \\
\dot{0} \\
\dot{ } \\
\dot{ } \\
\dot{ } \\
: \\
: \\
:\end{array}$ & $\begin{array}{l}\dot{0} \\
\dot{0} \\
\dot{0} \\
\dot{0} \\
\dot{0} \\
\dot{0} \\
\dot{0} \\
\dot{0} \\
\dot{0} \\
\dot{0}\end{array}$ & $\begin{array}{l}\dot{\bullet} \\
\dot{0} \\
\dot{0} \\
\dot{0} \\
\dot{0} \\
\dot{\bullet} \\
\dot{0} \\
\dot{\bullet} \\
\dot{\bullet}\end{array}$ & 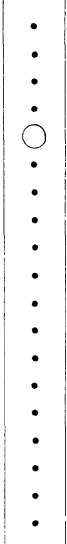 & $\begin{array}{c}0 \\
0 \\
\bigcirc \\
\bigcirc \\
0 \\
0 \\
\dot{0} \\
\dot{0} \\
\dot{0} \\
0 \\
\dot{0} \\
\dot{0} \\
\dot{0}\end{array}$ & $\begin{array}{l}\dot{\bullet} \\
\dot{0} \\
\dot{0} \\
\dot{0} \\
\dot{\cdot} \\
\dot{0} \\
\dot{0} \\
\dot{\cdot} \\
\dot{\cdot} \\
\dot{\cdot}\end{array}$ & 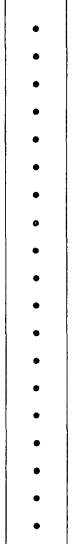 & 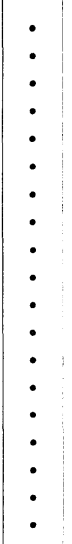 & $\begin{array}{c}\dot{0} \\
\dot{0} \\
\dot{0} \\
\dot{0} \\
\dot{0} \\
\dot{0} \\
\dot{0} \\
\dot{0} \\
\dot{ } \\
\dot{ }\end{array}$ & $\begin{array}{c}\dot{ } \\
\dot{0} \\
\dot{0} \\
\dot{0} \\
\dot{0} \\
\dot{0} \\
\dot{0} \\
\dot{0} \\
\dot{0} \\
\dot{0} \\
\dot{0}\end{array}$ & $\begin{array}{l}\dot{:} \\
\dot{:} \\
\dot{:} \\
\dot{:} \\
\dot{:} \\
\dot{:} \\
\dot{:} \\
\dot{:} \\
\dot{:}\end{array}$ \\
\hline 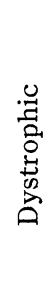 & $\begin{array}{l}\text { Suirennuma } \\
\text { Ichinuma } \\
\text { Nagaike } \\
\text { Misumaike } \\
\text { Shijūhachiike } \\
\text { Shibuike } \\
\text { Ozegahara pond } \\
\text { Ayamedaira moor } \\
\text { Kamagaike } \\
\text { Kurumayama moor }\end{array}$ & $\begin{array}{l}\text { A } \\
\text { F } \\
\text { F } \\
\text { F } \\
\text { F } \\
\text { F } \\
D \\
D \\
F \\
\text { F }\end{array}$ & $\begin{array}{l}\dot{\bullet} \\
\dot{0} \\
\dot{:} \\
\dot{0}\end{array}$ & $\begin{array}{l}\dot{:} \\
\dot{:} \\
\dot{:} \\
\dot{ } \\
\dot{ } \\
\dot{.}\end{array}$ & $\begin{array}{l}\dot{:} \\
\dot{:} \\
\dot{ } \\
\dot{ }\end{array}$ & $\begin{array}{l}\dot{:} \\
\dot{:} \\
\dot{:} \\
\dot{ } \\
\dot{ }\end{array}$ & $\begin{array}{l}\dot{:} \\
\dot{:} \\
\dot{:} \\
\dot{ }\end{array}$ & : & $\begin{array}{l}\dot{:} \\
\dot{.} \\
\dot{.} \\
\dot{.} \\
\dot{.}\end{array}$ & $\begin{array}{l}\dot{:} \\
\dot{:} \\
\dot{:} \\
\dot{ } \\
\dot{ }\end{array}$ & $\begin{array}{l}\dot{0} \\
\dot{0} \\
\dot{0}\end{array}$ & $\begin{array}{l}\dot{ } \\
\dot{0} \\
\dot{0} \\
\dot{\bullet} \\
\dot{\bullet}\end{array}$ & $\begin{array}{l}\dot{0} \\
\dot{0} \\
\dot{0} \\
\dot{0} \\
\dot{0} \\
\dot{ } \\
\dot{ }\end{array}$ & $\begin{array}{l}\dot{ } \\
\dot{ } \\
\dot{ }\end{array}$ & $\begin{array}{l}\dot{0} \\
\dot{0} \\
\dot{\bullet} \\
\dot{\cdot} \\
\dot{\cdot}\end{array}$ & $\begin{array}{l}\dot{\bullet} \\
\dot{0} \\
\dot{0} \\
\dot{\bigcirc} \\
0\end{array}$ \\
\hline 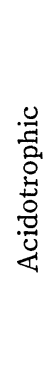 & $\begin{array}{l}\text { Katanuma } \\
\text { Akadoronuma } \\
\text { Akanuma } \\
\text { Hyötannuma } \\
\text { Kokenuma } \\
\text { Onumaike } \\
\text { Aodoronuma } \\
\text { Rurinuma } \\
\text { Aonuma } \\
\text { Akanuma (Hakkōda) } \\
\text { Bentennuma } \\
\text { Bishamonnuma } \\
\text { Midoronuma }\end{array}$ & $\begin{array}{l}\text { B } \\
\text { C } \\
\text { C } \\
\text { C } \\
\text { C } \\
\text { F } \\
\text { C } \\
\text { C } \\
\text { C } \\
\text { A } \\
\text { C } \\
\text { C } \\
\text { C }\end{array}$ & $\begin{array}{l}\dot{ } \\
\dot{\bullet} \\
\dot{0} \\
\dot{0} \\
\dot{0} \\
\dot{0}\end{array}$ & $\begin{array}{l}\dot{:} \\
\dot{.} \\
\dot{.} \\
\dot{.} \\
\dot{.} \\
\dot{.} \\
\dot{ }\end{array}$ & $\begin{array}{l}\dot{:} \\
\dot{ } \\
\dot{ } \\
\dot{ } \\
\dot{ } \\
\dot{ } \\
\dot{ }\end{array}$ & $\begin{array}{l}\dot{:} \\
\dot{.} \\
\dot{.} \\
\dot{.} \\
\dot{.} \\
\dot{.}\end{array}$ & $\begin{array}{l}\dot{ } \\
\dot{ } \\
\dot{ } \\
\dot{ } \\
\dot{ } \\
\dot{ } \\
\dot{0}\end{array}$ & $\begin{array}{l}\dot{\bullet} \\
\dot{.} \\
\dot{0} \\
\dot{ } \\
\dot{ } \\
\dot{0} \\
\dot{0}\end{array}$ & $\begin{array}{l}\dot{ } \\
\dot{ } \\
\dot{ } \\
\dot{ } \\
\dot{ } \\
\dot{ } \\
\dot{ } \\
\dot{ }\end{array}$ & $\begin{array}{l}\dot{ } \\
\dot{ } \\
\dot{ } \\
\dot{ } \\
\dot{ } \\
\dot{ } \\
\dot{ }\end{array}$ & $\begin{array}{l}\dot{ } \\
\dot{ } \\
\dot{ } \\
\dot{ } \\
\dot{0} \\
\dot{0} \\
\dot{\bullet}\end{array}$ & $\begin{array}{l}0 \\
0 \\
0 \\
0 \\
\dot{0} \\
\dot{0} \\
\dot{ } \\
\dot{ }\end{array}$ & $\begin{array}{l}\dot{0} \\
\bigcirc \\
\bigcirc \\
ن \\
\bigcirc \\
\bigcirc \\
\dot{\bigcirc}\end{array}$ & 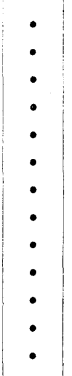 & $\begin{array}{l}\dot{:} \\
\dot{:} \\
\dot{:} \\
\dot{:} \\
\dot{:} \\
\dot{:}\end{array}$ & 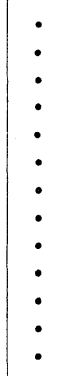 \\
\hline
\end{tabular}
* Prefectures: A, Aomori;
B, Miyagi;
C, Fukushima;
E, Tochigi;
F, Nagano;
G, Yamanashi.
D, Gunma; 
spora longissima dominated in the acidotrophic lakes. The distribution of the former species was restricted in the acidotrophic lake water containing large amounts of mineral elements $\left.{ }^{18}\right)$. No aquatic fungus was found in Lake Katanuma and Akadoronuma. This is caused by the strong acidity as well as by the chemical specificity of lake water $\left.{ }^{18}\right)$.

Among many factors determining the distribution of species in lakes, the physicochemical properties of the lake water are considered to be the most essential. The water of the dystrophic lakes revealed in tests strong acidity and contained large amounts of humic substances, while the water of the acidotrophic lakes are very rich in inorganic acids. The strong acidity of the water of both lake types may be too toxic for the aquatic fungi to distribute in them. However, the mijeral salts such as sulfate of iron and calcium, were very effective on the growth of the aquatic fungi. According to the water analysis of the acidotrophic lakes, some of mineral elements were measured as follows: $\mathrm{SO}_{4}, 75-442 ; \mathrm{Fe}, 0.01-278 ; \mathrm{Mn}, 1.0-9.1 ; \mathrm{Ca}, 32-495 ; \mathrm{Cl}$, $5-202 \mathrm{in} \mathrm{mg./l}$. These amounts of mineral elements may provide the factors that decide the distribution of aquatic Hyphomycetes.

\section{Physiological specificity of the fungi and lake type}

On the distribution of aquatic Hyphomycetes in many Japanese lakes, it is clear that the distribution is determined by the acidity, mineral components and some other factors of the lake water. To make clear the specificity of lake water to the aquatic fungi, some laboratory experiments were carried out.

The aquatic Hyphomycetes were inoculated on yeast extract glucose agar. Under such conditions the mycelial growth occurred but never the conidia formation. A piece of mycelium of the fungi was then submerged in the lake water of different lake types. After this was allowed to stand for a day or two at room temperature, the formation of conidia was observed (Table 2).

The conidia formation differed with the water of different lake types and different species. The conidia were quickly formed in the water of the harmonic lakes, while they were very slight or non-existent in the dystrophic and acidotrophic lake water.

The conidia of Tricladium gracile, Lemonniera aquatica and Anguillospora longissima were formed even in the water of the acidotrophic lakes. These species were frequently found in the inorganic acidotrophic lakes in Japan. No conidia formation, however, was observed in strongly acid water of Lake Katanuma and Akadoronuma. On the other hand, the conidia of Clavariopsis aquatica, Tetrachaetum elegans and Articulospora tetracladia, which were found only in the harmonic lakes, were not formed in the water of the acidotrophic lakes. The result was in accord with the observations made by the writers in the natural lakes.

The results obtained in dystrophic lakes are very complicated. The conidia formation of all species occurred in the water of Lake Nagaike, while the water of ponds of Kinunuma High Moor very toxic to some fungi. The disharmonity in the distribution of fungi may be caused by the humic substances dissolved in lake water. 
Table 2. The conidia formation of aquatic Hyphomycetes in the lake waters of diverse lake types.

\begin{tabular}{|c|c|c|c|c|c|c|c|}
\hline 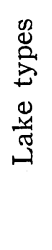 & Lakes & 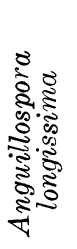 & 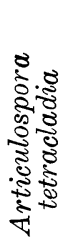 & 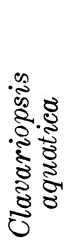 & 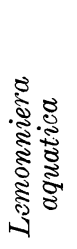 & 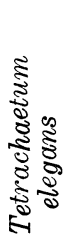 & 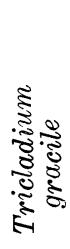 \\
\hline 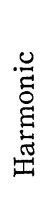 & 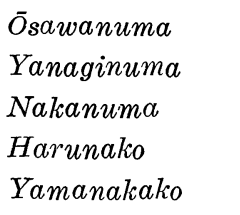 & $\begin{array}{l}\text { W } \\
\mathrm{H} \\
\mathrm{H} \\
\mathrm{H} \\
\mathrm{H}\end{array}$ & $\begin{array}{l}\text { H } \\
\text { H } \\
H \\
H \\
\text { W }\end{array}$ & $\begin{array}{l}\text { H } \\
\mathrm{H} \\
\mathrm{H} \\
\mathrm{H} \\
\mathrm{H}\end{array}$ & $\begin{array}{l}\mathrm{H} \\
\mathrm{H} \\
\mathrm{H} \\
\mathrm{H} \\
\mathrm{H}\end{array}$ & $\begin{array}{l}\text { W } \\
\text { W } \\
\mathrm{H} \\
\mathrm{W} \\
\mathrm{H}\end{array}$ & $\begin{array}{l}\text { Ht } \\
\text { W } \\
\mathrm{H} \\
\mathrm{H} \\
\mathrm{H}\end{array}$ \\
\hline 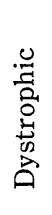 & $\begin{array}{l}\text { Nagaike } \\
\text { Shibuike } \\
\text { Shijūhachiike } \\
\text { Ozegahara pond } \\
\text { Kinunuma }\end{array}$ & $\begin{array}{l}\text { H } \\
+ \\
H \\
H \\
-\end{array}$ & $\begin{array}{l}\text { H } \\
H \\
H \\
H \\
H\end{array}$ & $\begin{array}{l}\text { W } \\
- \\
- \\
H \\
-\end{array}$ & $\begin{array}{l}\text { W } \\
H \\
H \\
H \\
H\end{array}$ & $\begin{array}{l}\text { W } \\
H \\
H \\
- \\
H\end{array}$ & $\begin{array}{l}\text { H } \\
H \\
H \\
H \\
H\end{array}$ \\
\hline 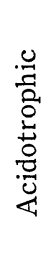 & $\begin{array}{l}\text { Katanuma } \\
\text { Akadoronuma } \\
\text { Akanuma } \\
\text { Rurinuma } \\
\text { Aonuma } \\
\text { Bishamonnuma }\end{array}$ & $\begin{array}{l}- \\
- \\
+ \\
H \\
m \\
H\end{array}$ & $\begin{array}{l}- \\
- \\
- \\
- \\
+ \\
+\end{array}$ & $\begin{array}{l}- \\
- \\
- \\
- \\
+ \\
+\end{array}$ & $\begin{array}{l}- \\
- \\
+ \\
H \\
H \\
H\end{array}$ & $\begin{array}{l}- \\
- \\
- \\
- \\
+ \\
-\end{array}$ & $\begin{array}{l}- \\
- \\
H \\
H \\
H \\
H\end{array}$ \\
\hline
\end{tabular}

\section{Summary}

The relation between the distribution of aquatic Hyphomycetes and the lake types was studied in some Japanese lakes. The aquatic Hyphomycetes were very rich in both quantity and number of species in the harmonic lakes, while they were slight or non-existent in the dystrophic and acidotrophic lakes. Tricladium gracile var. oxyphilum and Anguillospora longissima were the dominating species in the acidotrophic lakes, and Varicosporium elodeae was found only in the dystrophic lakes.

The experiments were carried out in the laboratory on the effect of the lake water upon the conidia formation of the fungi. The conidia were easily produced in the water of the harmonic lakes, but never in some acidotrophic one. Anguillospora longissima, Lemonniera aquatica and Tricladium gracile seem to be suitable to the acidotrophic water containing large amounts of mineral elements. The results were in accord with the observation in the natural lakes.

The writers wish to express their thanks to Prof. H. Indoh and Prof. H. Ito for their instructive guidance and advice. Also to Dr. S. Ichimura, Prof. T. Tatsuno 
and T. Matsumoto, the writers are indebted for much valuable advice during this work.

\section{References}

1) Ingold, C. T., Trans. Brit. Mycol. Soc. 25: 339 (1942). $\quad$ 2) — , ibid. 26: 104 (1943). 3) , ibid. 26: 148 (1943). 4) —, New Phyt. 40: 139 (1943). 5) —, Trans. Brit. Mycol. Soc. 27: 35 (1944). 6) —, Proc. Linn. Soc. Lond. 157: 43 (1945). 7) 一, Trans. Brit. Mycol. Soc. 32: 341 (1949). 8) —u ibid. 35: 158 (1952). 9) —, ibid. 35: 66 (1952). 10) —, Rep. Internat. Bot. Congress, Sect. 19: 62 (1954). 11) -- , and Cox, V. J., Trans. Brit. Mycol. Soc 40: 155 (1957). 12) Ranzoni, F. V., Falowia 4: 353 (1953). 13) —-, Amer. Journ. Bot. 43: 13 (1956). 14) Nilsson, S., Sven. Bot. Tidskr. 52: 291 (1958). 15) Tubaki, K., Bull. Nat. Sci. Mus. Tokyo 3: 249 (1957). 16) Waid, J. S., Trans. Brit. Mycol. Soc. 37: 420 (1954). 17) Willen, T., Bot. Not., 111, Fasc. 2: 431 (1958). 18) Suzuki, S., and H. Nimura, Bot. Mag. Tokyo 73: 360 (1960).

\section{摘 要 \\ 鈴木静夫·二村坦孝： 水棲不完全菌類の分布と湖沼型}

日本の 42 個の湖沼の水棲不完全菌類を調查し, 特に湖沼型と種類の分布との関係を明らかにした. 水 辇不完全菌類は調和型の湖沼には種類が豊富であるが，酸栄養湖や腐植栄養湖で崜類が少ない。すなわ ら，酸栄養湖には特異な水に適応した Tricladium gracile var. oxyphilum と Anguillospora longissima が優占し，腐植栄羪湖にはV Varicosporium elodeae がもっとも普通に見られるが，調和湖に見ら れる種類はほとんど棲息しない.

異なった湖沼型に属する湖沼の水に純粋に培羪した水椿不完全菌類の菌系を入れ，分生子の形成の有無 を钼察した。その結果，調和湖の湖水中で汇各種類ともよく分生子が形成されたが，酸栄養湖の湖水中で はこの型の湖沼に多く見られる Tricladium gracile, Anguillospora longissima, Lemonniera aquatica の 3 種だけが分生子を生じ，これらの種類が多量の無機塩類を含有している酸栄養湖の水に適応している ことが明らかになり，野外での観察結果が裏づけられた。しかし，腐植栄養湖の湖水中では比較的よく分 生子が形成され，実際に湖沼にはほとんど菌類が凄息して和らず，両者の結果が一致しない。（東京理科 大学薬学部微生物化学教室; 東京教育大学理学部植物学教室） 